\title{
Surface Antigen (HBsAg) Negative Hepatitis B virus in Bangladesh: Warrants the Screening for Blood Donors
}

\author{
SALAHUDDIN MAHMUD ${ }^{1}$, MANJUMA RAHMAN $^{2}$, FARHANA TASNEEM $^{3}$, MAHENAZAFROZ $^{4}$, SYED $^{2}$ \\ SHAFI AHMED ${ }^{5}$, MANZOOR HUSSAIN ${ }^{6}$
}

\begin{abstract}
In every case of blood transfusion, so called proper donor screening is done every day. At the end of beautiful day, after reviewing lots of national and international guidelines and papers of blood transfusion, proved that blood donor screening methods \& tests are not adequate \& appropriate according to WHO. Lots of multi-transfused thalassemic \& hemophiliac patients getting hepatitis $B$ virus undoubtedly. Implementations of strict donor selection criteria and use of sensitive laboratory screening tests reduce the incidence of HBV transfusion. These courageous heartiest review may awake the decision makers thinking rethinking about HBV free blood transfusion service in Bangladesh.
\end{abstract}

Key words: Blood transfusion, Blood donor screening, transfusion transmissible infections.

\section{Introduction}

Blood transfusion is the process of transferring blood or blood based products from donor into the circulatory system of recipient. ${ }^{1}$ Transfusion of blood \& blood component as a specialized modality of patient management saves million of lives each year worldwide. ${ }^{2}$ The microbial agents are transmissible by blood transfusion \& can cause morbidity \& mortality in recipients. The infectious agents may present in the blood for long periods, sometimes in high titers, stability in blood stored at $4^{\circ} \mathrm{C}$ or lower, long incubation period before the appearance of clinical signs, asymptomatic phase or only mild symptoms in the blood donor, hence not identifiable during the blood donor selection process. ${ }^{3}$

1. Assistant Professor, Pediatric Gastroenterology, Hepatology \& Nutrition, Bangladesh Institute of Child Health, Dhaka Shishu (Children) Hospital

2. Consultant, Blood Transfusion Department, Square Hospital Limited (SHL), Dhaka

3. Registrar, Neonatology, Apollo Hospitals, Dhaka

4. Assistant Professor of Gynaecology \& Obstetrics, National Institute for Cancer Research Hospital (NICRH)

5. Professor \& Head, Pediatric Gastroenterology, Hepatology \& Nutrition, Bangladesh Institute of Child Health, Dhaka Shishu (Children) Hospital

6. Professor \& Head, Pediatric Medicine \& Pediatric Cardiology, Bangladesh Institute of Child Health, Dhaka Shishu (Children) Hospital.

Correspondence to: Dr. Salahuddin Mahmud, Assistant Professor, Dhaka Shishu (Children) Hospital, Dhaka, Email: drsmbablu@gmail.com

Received: 20 November 2017 Accepted: 30 November 2017
In developing countries, blood safety remains an issue of major concern. Preventing the transmission of HBV through blood transfusion in developing countries are difficult. The priority objective of blood transfusion service is to ensure safety, adequacy, accessibility \& efficiency of blood supply at all levels. These strategies have been extremely effective but transmission of HBV still occurs. Inability of the test to detect the disease in the pre-seroconversion or window phase of their infection, immunologically variant viruses, nonseroconverting chronic or immunosilent carriers \& laboratory testing errors may be the possible causes. ${ }^{4}$

Bangladesh, a developing country of South-East Asia, has a population of 160 million. HBV is the most common cause of chronic liver diseases including cirrhosis of liver, hepatic failure, \& hepatocellular carcinoma. The risk of acquiring new HBV infection has been reduced in Bangladesh with the introduction of hepatitis $B$ surface antigen (HBsAg) screening in blood donors. However, with the advent of 'occult HBV infection', it is now clear that many HBV-infected subjects may not express HBsAg (surface antigen to HBV) but may harbor HBV DNA. ${ }^{5}$ From different studies of blood \& organ recipients have recently shown HBV transmission from anti-HBc positive (core antibody against the core antigen), HBsAg negative donors, even when HBV DNA was undetectable in the donor. ${ }^{6}$ In fact, the blood transfusion system of Bangladesh has not been optimized to tackle these situations. ${ }^{5}$ 


\section{Hepatitis B Virus (HBV)}

Hepatitis $B$ virus (HBV) is an enveloped DNA virus that infects the liver and causes hepatocellular necrosis and inflammation. HBV infection can be either acute or chronic, and may range from asymptomatic infection or mild disease to severe or rarely fulminant hepatitis. ${ }^{7}$

\section{Epidemiology \& Burden of HBV}

Around 2 billion people have evidence of past or present infection with HBV, \& 240 million are chronic carriers of HBV surface antigen (HBsAg). Worldwide, it is estimated that around 650000 people die each year from the complications of chronic hepatitis $B$ virus infection. ${ }^{7}$

\section{Hepatitis B Virus (HBV) Infection}

New-onset hepatitis $B$ infection that may or may not be icteric or symptomatic. ${ }^{7}$ For good understanding of HBV infection should know about some important conditions (Fig 1) 7,8,9,10

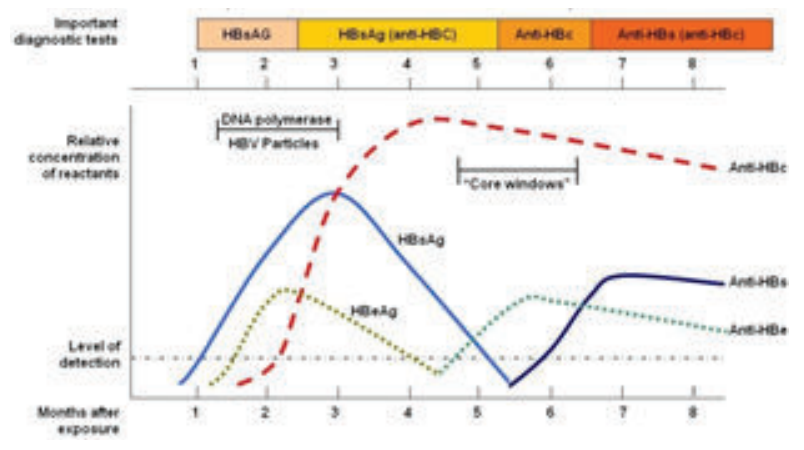

Fig.-1: Profile of HBV infection ${ }^{11}$

\section{Acute Hepatitis B Virus (HBV) Infection}

Diagnosis of acute HBV infection is based on detection of hepatitis $B$ surface antigen $(\mathrm{HBsAg})$ and $\lg \mathrm{M}$ antibodies to hepatitis $\mathrm{B}$ core antigen (antiHBclgM). 7,8,9,10

\section{Natural Immunity}

Recovery is accompanied by clearance of HBsAg with seroconversion to anti-HBs (antibodies to hepatitis B surface antigen) usually within 6 months. ${ }^{7,8,9,10}$

\section{Chronic Hepatitis B Virus (HBV) Infection}

Persistence of hepatitis B surface antigen (HBsAg) for six months or more along with anti-HBclgG (lgG antibodies to hepatitis $B$ core antigen) after acute infection indicate chronicity. Age is a key factor in determining the risk of chronic infection (Figure 3.1). Chronicity is common following acute infection in neonates $(90 \%$ of neonates born to hepatitis B e antigen [HBeAg]-positive mothers) \& in young children under the age of 5 years (20-60\%), but occurs rarely $(<5 \%)$ when infection is acquired in adulthood. Worldwide, the majority of persons with CHB were infected at birth or in early childhood. $7,8,9,10$

\section{Incubation Period:}

The time between exposure of HBV and appearance of symptoms. ${ }^{7,8,9,10}$

\section{Window Period:}

The time interval between the disappearance of HBsAg and the appearance of anti-HBS (antibody to surface antigen). $7,8,9,10$

\section{Occult Hepatitis B Virus (HBV) Infection:}

Absence of HBsAg despite presence of anti-HBc (core antibody) and HBV-DNA $<1000$ copies/ml or $<200$ IU/ $\mathrm{ml}$ (Fig 2) $7,8,9,10$

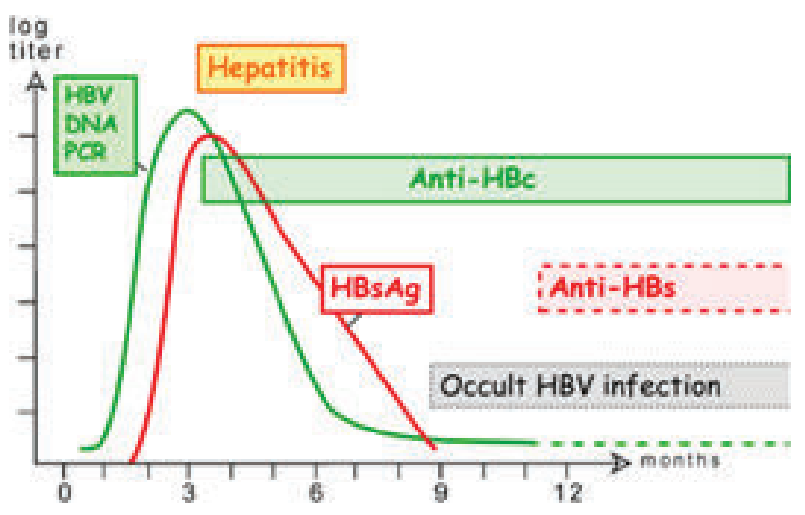

Fig.-2: Occult HBV infection ${ }^{12}$

\section{Transfusion Transmissible Infections (TTI)}

Many viruses [mostly hepatitis B virus, hepatitis C virus, HIV \& less commonly cytomegalovirus (CMV) \& Epstein Barr Virus (EBV)], bacteria (Treponema pallidum) \& protozoa (malarial parasite) can be transmitted by transfusion. ${ }^{13,14}$ Like other developing countries, blood banking in Bangladesh does not get enough attention for development from authorities. Many blood recipients remained at risk of TTI transmission as a result of poor blood donor recruitment $\&$ the use of low-quality testing in TTI screening. ${ }^{15}$ 


\section{Transmission of HBV through transfusion}

HBV is spread predominantly by percutaneous or mucosal exposure to infected blood. ${ }^{7}$ Several studies from different countries including Bangladesh indicates that, blood transfusion is the main source for transmission of HBV (Table I \& II).

Table I

Seroprevalence of HBV among multi-transfused Thalassemic children

\begin{tabular}{lccc}
\hline Country & Year & $\begin{array}{c}\text { Total } \\
\text { Children }\end{array}$ & $\begin{array}{c}\text { HBsAg } \\
\text { Positive }\end{array}$ \\
\hline India $^{16}$ & 2017 & 211 & $10(2.3 \%)$ \\
Egypt $^{17}$ & 2016 & 97 & $4(4.1 \%)$ \\
Iran $^{18}$ & 2016 & 90 & $3(3.3 \%)$ \\
Pakistan $^{19}$ & 2015 & 145 & $5(3.5 \%)$ \\
Malaysia $^{20}$ & 2015 & 100 & $4(4.0 \%)$ \\
Bangladesh $^{21}$ & 2014 & 200 & $13(6.5 \%)$ \\
Bangladesh $^{22}$ & 2013 & 100 & $3(3.0 \%)$ \\
India $^{23}$ & 2013 & 218 & $8(3.6 \%)$ \\
Bangladesh $^{24}$ & 2012 & 95 & $21(22.1 \%)$ \\
Bangladesh $^{25}$ & 2007 & 42 & $8(19 \%)$ \\
Bangladesh $^{26}$ & 2003 & 152 & $21(13.8 \%)$ \\
\hline
\end{tabular}

Table II

Seroprevalence of HBV among multi-transfused Hemophiliac children

\begin{tabular}{lccc}
\hline Country & Year & $\begin{array}{c}\text { Total } \\
\text { Children }\end{array}$ & $\begin{array}{c}\text { HBsAg } \\
\text { Positive }\end{array}$ \\
\hline Pakistan ${ }^{27}$ & 2017 & 396 & $12(3.0 \%)$ \\
Iran ${ }^{28}$ & 2015 & 146 & $2(1.4 \%)$ \\
USA $^{29}$ & 2012 & 400 & $32(8.0 \%)$ \\
Iran $^{30}$ & 2007 & 81 & $8(9.8 \%)$ \\
Iran $^{31}$ & 2002 & 101 & $27(26.7 \%)$ \\
\hline
\end{tabular}

Donor screening tests for HBV in Bangladesh and Abroad

Nowadays in Bangladesh, routine screening of blood donors for HBV is only HBsAg (surface antigen to HBV). ${ }^{32}$ Along this test, International organizations added some recent tests for prevention of HBV transmission. With HBsAg (surface antigen), American red cross, ${ }^{33}$ Australian red cross, ${ }^{34}$ U.S. food and drug administration (FDA), ${ }^{35}$ United Kingdom (UK) 36 \& Singapore health science authority 37 recommends for blood donor screening anti-HBc [core antibody against the core antigen $(\mathrm{HBcAg})$ (these antigen usually present in liver not in serum)] and Nuclieic acid testing (NAT) ${ }^{38}$ (It is a molecular technique for screening of HBV which providing an additional layer of blood safety). But Centers for disease control and prevention (CDC) ${ }^{39}$ and World Health Organization (WHO) ${ }^{13}$ recommends cost effective approach for developing countries like Bangladesh are serum HBsAg and Anti-HBc. When both are negative or HBsAg negative but Anti-HBc positive then they advised should do anti-HBs titer \& if it is greater than $100 \mathrm{mIU} / \mathrm{ml}$ then they allow the donor for transfusion. ${ }^{13}$

\section{Limitations of Hepatitis B Virus Surface Antigen (HBsAg)}

Surface antigen (HBsAg) usually appear after 3-4 weeks of exposure \& disappear before window period if not develop chronicity. Core antibody usually appear just after appearance of HBsAg \& persist throughout the life. HBV-DNA appear within a week of exposure \& diagnose even $<75$ copies/ml. $7,8,9,10$ So, Only HBV surface antigen (HBsAg) marker does not always reflect the presence or absence of HBV infection. HBsAg may absent in incubation period, 40,41 window period, $40,41,42$ occult HBV infection, ${ }^{5,38}$ mutant to surface antigen (HBsAg) ${ }^{41,42}$ \& even after reactivation of resolved HBV infection. ${ }^{40,42}$ Blood that is free of HBsAg but has high-titer antibodies against hepatitis $B$ core antigen (anti-HBc) in the absence of antibodies against hepatitis $B$ surface antigen (anti-HBs) can also transmit HBV infection. However, a small proportion of donors with anti-HBc in the absence of $\mathrm{HBsAg}$ have circulating HBV DNA \& may have a risk of infectivity. ${ }^{43}$

Core antibody Situation in Bangladesh and Abroad Transmission of hepatitis B virus (HBV) infection through donated blood is a common occurrence. In blood bank, screening for HBsAg is carried out routinely to detect HBV infection. Despite testing for HBsAg in blood donors, transfusion-associated HBV infection continue to be a major problems in Bangladesh. Antibodies to hepatitis B core (HBc) antigen are marker of acute, chronic, or resolved HBV infection \& remain detectable for life. These can be present in the absence of both HBsAg \& anti-HBs 
antibodies. Anti-HBc is therefore detected in anyone who has been infected with hepatitis $B$ virus. ${ }^{41}$

In a study of Bangladesh, Rahman et al. ${ }^{41}$ stated that among 52 core antibody (Anti-HBc) positive donor who are HBsAg negative, HBV-DNA positive in 16 $(30.7 \%)$ cases. Again those who are HBV-DNA positive their anti-HBs (antibody to surface antigen) titer were higher (>10 $\mathrm{mIU})$ in only $6(33.33 \%)$ cases. They concluded that, core antibody should be routinely included on blood donor screening \& if found positive regardless of anti-HBs titer blood should be discarded. 41 Jahan et al. ${ }^{5}$ also stated the same phenomena. Among 398 HBsAg negative donors, core antibody (anti-HBc) positive $82(20.6 \%)$. Again who are anti$\mathrm{HBc}$ positive, HBV-DNA present in 7 (8.5\%) donors. They concluded with surface antigen negative blood is not capable of blocking HBV transmission. Developing country like Bangladesh may apply core antibody (anti-HBc) for donor screening. ${ }^{5}$

A study from West Bengal, India, a neighboring Indian province of Bangladesh has reported that $21.3 \%$ HBsAg negative \& anti-HBc-positive blood donors were harboring HBV DNA in their blood. ${ }^{44}$ Another study from India also showed that $7.5 \%$ of $\mathrm{HBsAg-negative,}$ anti-HBc positive blood was expressing HBV DNA. Surprisingly, $4.6 \%$ people expressing both anti-HBc $\&$ anti-HBs were also expressing HBV DNA in their blood. 45

Presence of HBV DNA in HBsAg-negative blood donors has also been reported from other Asian countries, such as Iran that showed HBV DNA among 12.2\% HBsAg-negative, anti- HBc positive donors. ${ }^{46}$ Studies from Lebanon \& Pakistan have revealed HBV DNA among 2.8\% \& 2.9\% HBsAg negative, anti-HBcpositive blood donors, respectively. 47,48

Despite all these beneficial \& informative study, No blood transfusion centers of Bangladesh do core antibody except two corporate hospitals. One is Square Hospital Limited ${ }^{49}$ \& another is Apollo Hospital, Dhaka. ${ }^{50}$ They routinely done anti-HBc for donor screening \& if positive then deferred them from blood transfusion. Based on these observations, policy makers \& professional organizations of these countries have been trying to optimize their blood transfusion system. ${ }^{5}$ However, these scientific developments have not influenced the ongoing blood transfusion program of Bangladesh, even though high prevalence of antiHBc $(22.6 \%)$ has been reported among healthy subjects of Bangladesh. Additionally, anti-HBc- positivity is extremely high even among children below the age of 5 years (16.3\%) \& increased to $30 \%$ among family members. ${ }^{51}$

In this dangerous situation, almost nothing is known about the real extent of problem with anti-HBc positivity in this country. Recently, nucleic acid testing (NAT) has been adopted by many countries to avoid transfusion-induced hepatitis. ${ }^{52}$ Also, we would not advocate for immediate starting of NAT for donor screening in Bangladesh, as this is neither feasible nor acceptable in the context of present socioeconomic condition of this country. It is usually discussed that NAT establishment is a costly endeavor in Bangladesh \& other developing countries. ${ }^{5}$

\section{Tests methods}

According to WHO \& National guideline, the main types of assay used for blood screening of HBV are: ${ }^{32}$

- Immunoassays (IAs):

- Enzyme immunoassays (EIAs)

- Chemiluminescent immunoassays (CLIAs)

- Rapid/simple single use assays (rapid tests)

- Nucleic acid amplification technology (NAT) assays.

\section{Universal Choice}

The blood transfusion department of medical colleges, institutes \& specialized hospitals should perform EIAs \& CLIAs for blood screening in addition to the current system of rapid testing. ${ }^{32}$

\section{In Special Situation}

Only rapid tests may be considered in case emergency screening (when blood is needed urgently) or in remote areas with low workloads or limited number of tests are performed daily \& limited facilities, when equipment is lacking or where there may be no electricity e.g. district blood centers \& Upazila health complexes. 32

\section{Why EIAs \& CLIAs Rather than Strip}

In case of rapid test, lots of false positive/negative results may occur. It is most commonly used, only 30 taka/strip, less sensitive \& specific, manual entry of test results \& not recommended by WHO as a universal screening of blood donors in Bangladesh. When false positive results occur, prospective blood donors are unnecessarily excluded from blood donation. On the other $h \&$, when false negatives occur, this poses a great challenge to the quality \& reliability 
of blood screening \& to patient safety. Errors may also be produced if samples for re-testing are improperly stored \&/or transported. On the other side, quite unlikely to occur when screening is done by EIA, Chemiluminoassay, or PCR technology. ${ }^{32}$

\section{Present Situation in Bangladesh}

In Bangladesh, Transfusion Transmissible Infections (TTI) screening is done mainly by rapid assay. Only at private sector centers (Square Hospital Limited 49 \& another is Apollo Hospital, Dhaka ${ }^{50}$ ) are screening done by EIA/ CLIA (Chemiluminescent Assay). The blood donation system in Bangladesh is decentralized; all centers collect, \& process \& distribute blood. A beautiful study was done in 2013, which was organized by WHO, DGHS (Director General Health Services) \& IEDCR (Institute of Epidemiology, Disease Control \& Research) to assess the donor screening quality of different blood transfusion centers of Bangladesh. A total of 12 centers from Dhaka city (Apollo hospital, Square hospital, United hospital, LabAid hospital, Armed forces institutes of pathology Bangladesh medical college hospital, Cancer \& rehabilitation hospital, Chest diseases hospital, Kidney \& urology hospital, Institutes of child \& maternal health etc) \& 15 centers from outside the Dhaka (Rajshahi medical college hospital, Khulna medical college hospital, Faridpur medical college hospital, Comilla medical college hospital \& lots of district hospitals) were included in this study. A total 915 blood samples were received from testing centers \& all samples were accepted for re testing in IEDCR. Out of 27 testing centers, results from 18 centers were correct $(66.67 \%)$ $\&$ those from 9 centers were incorrect $(33.33 \%$ ) when compared with the results obtained at IEDCR. Among incorrect results, HBV $(53.3 \%)$ is the dominant one followed by HCV $(40 \%)$ \& malaria $(6.7 \%)$. No results of disparity observed among HIV \& syphilis cases. ${ }^{53}$

\section{Conclusions}

Although so called proper donor screening prior to blood transfusion \& vaccination present, actually they are unable to prevent transmission of HBV. The physicians, hepatologists, academicians \& policy makers are equally unaware of the seriousness, loop holes \& magnitudes of ongoing blood transfusion program of this country. The hazards of blood transfusion, specially the risk of transfusion transmissible infections specially HBV are now the burning issue. The risk of disease transmission increases many fold if blood donor selection is inappropriate \& method of testing is inadequate. Percentage of core antibody (anti-HBc) positivity with surface antigen (HBsAg) negativity of healthy donors warrants the decision makers for rethinking about occult/silent HBV infection. Transfusions should be planned judiciously \& side by side, efforts should be made to minimize the risk of hepatitis $B$ transmission through adopting the guidelines from WHO for safe blood transfusion. Awareness \& knowledge would be the key to prevent the transfusion of transmissible diseases.

\section{Recommendations}

- Donor screening should be on Enzyme immunoassays (EIAs) \& Chemiluminescent immunoassays (CLIAs) in place of strip method.

- Regarding HBV, Core antibody (anti-HBc) should include in national donor screening program.

- In future, nucleic acid testing (NAT) for HBV should be included for safe blood transfusion in Bangladesh.

\section{Future Prospect}

Establishment of a nationally coordinated blood transfusion service, collection of blood only from voluntary donors, testing of all blood for compatibility \& transfusion transmissible infections (TTIs) with appropriate method of testing \& reduction of unnecessary transfusion will be the key factors for excellent blood transfusion service (BTS) in future. It is widely expected that BTS will be able to supply HBV free blood from voluntary blood donors to all parts of the country in timely manner with sufficient quantity.

\section{References}

1. Khanum $\mathrm{H}$, Khanom M, Banu $\mathrm{H}$, Muznebin $\mathrm{F}$, Alam S, Shafiullah AZM. Blood transfusion transmitted infectious diseases (HIV, HBV, HCV, Syphilis \& Malaria) among the voluntary blood donors in Dhaka, Bangladesh. Bangladesh J Zool 2014; 42(1): 77-84.

2. Chowdhury FS, Begum HA, Adnan SD, Hoque $M M$, Hossain MZ, Siddiqui MAE. Study on screening tests among the blood donors in Dhaka Medical College Hospital, Bangladesh. J Dhaka Med Coll 2010; 19(1): 16-18.

3. World Health Organization. Screening donated blood for transfusion transmissible infections: Recommendations. Geneva: WHO 2010; 1-72. 
4. Saha SK, Banik RK, Saha MR, Habibullah MM, Mahtab MA. Prevalence of transfusion transmitted infection in healthy blood donors in Sir Salimullah Medical College Dhaka, Bangladesh. Euroasian J Hepato-Gastroenterol 2011; 1(2): 68-70.

5. Jahan M, Islam MA, Akbar SMF, Takahashi K, Tabassum S, Rahmen A et al. Anti- HBc Screening of Blood Donors in Bangladesh: Relevance to Containment of HBV Propagation. J CLIN EXP HEPATOL 2016; 6: 115-118.

6. Walz A, Wirth S, Hucke J, Gerner P. Vertical transmission of hepatitis $B$ virus (HBV) from mothers negative for HBV surface antigen \& positive for antibody to HBV core antigen. J Infect Dis. 2009; 200(8): 1227-1231.

7. World Health Organization. Guidelines for the prevention, care \& treatment of persons with chronic hepatitis B infection. Geneva: WHO 2015; 1-166.

8. Terrault NA, Bzowej NH, Chang KM, Hwang JP, Jonas MM, Murad MH. AASLD Guidelines for Treatment of Chronic Hepatitis B. HEPATOLOGY 2015; 00 (00): 1-23

9. World Gastroenterology Organisation. Practice guideline: Hepatitis B. Milwaukee: WGO 2015; 1-35.

10 Centers for disease control \& prevention. Sexually transmitted diseases treatment guidelines. Atlanta: CDC; 2015.

11. Firman G. Serologic Testing for the Diagnosis of Hepatitis B Virus (HBV) Infection. Medical Criteria 2011.

12. Gerlich WH. Medical virology of hepatitis B: How it began \& where we are now. Virology J 2013; 10: $1-25$.

13. World Health Organization. Blood donor selection: Guideline on assessing donor stability for blood donation. Geneva: WHO 2012; 1-128.

14. Centers for disease control \& prevention. Donor screening \& testing. Atlanta: CDC 2013.

15. Islam MB. Blood transfusion services in Bangladesh. Asian J Transf Sci 2009; 3(2): 1-3.

16. Mittal K, Abrol P, Yadav J. Prevalence of transfusion transmitted infections amongst multiple blood transfused patients of â- thalassemia major in a tertiary care hospital. Int J Res Med Sci. 2017 Jan; 5(1): 181-185.

17. Mahmoud RA, El-mazary AAM, Khodeary A. Seroprevalence of Hepatitis C, Hepatitis B, Cytomegalovirus, \& Human Immunodeficiency Viruses in Multitransfused Thalassemic Children in Upper Egypt. Advances in Hematology 2016; 16(1): 1-7.

18. Bazi A, Mirimoghaddam E, Rostami D, Dabirzadeh M. Characteristics of Seropositive Hepatitis B \& C Thalassemia Major Patients in South-East of Iran. Biotech Health Sci. 2016; 3(2): 1-6.

19. Sheikh MA, Rabbani MW, Ali Z, Babar Z, Iqbal I. Prevalence of Hepatitis B \& Hepatitis C in Thalassemia Major Patients receiving Multiple Transfusions at the Children's Hospital Multan. Pak Pediatr J 2015; 39(2): 69-72.

20. Haque ATME, Latiff HZBA. Prevalence of Hepatitis B \& Hepatitis C Infections among Multitransfused Thalassaemic Patients. PTB Reports 2015; 1(2): 69-72

21. Chakrabarty $P^{1}$, Rudra $S$, Hossain MA. Prevalence of HBV \& HCV among the multitransfused beta thalassemic major patients in a day care centre of blood transfusion department of Mymensingh Medical College Hospital. Mymensingh Med. j. 2014; 23(2): 235-241.

22. Karim AKMR, Islam A, Jamal CY, Matin A, Hossain M, Shafiullah M et al.Seroprevalence of Hepatitis B, Hepatitis C \& Human Immunodeficiency Virus Among Multitransfused Thalassaemic Children in Dhaka, Bangladesh. BANGLADESH J CHILD HEALTH 2013; 37 (3): 146-153.

23. Mankad GP. Singh SP. Incidence of veral hepatitis in thalassemic patients as a consequence of multiple blood transfusions. International J Scien \& Res Pub 2013; 3(8): 1-4.

24. Ahmed FS, Joarder SU, Islam N, Akter M, Kamal IM. Transfusion transmitted hepatitis $B$ virus among multitransfused thalassemic children in a tertiary health care center in Bangladesh. J Enam Med Col 2012; 2(2): 56-61.

25. Shekhar HU, Kabir Y, Hossain M, Uddin M, Jannat KK, Hossain $S$ et al. Blood transfusionmediated viral infections in thalassemic children in Bangladesh. J. Med. Sci. 2007; 7(1): 131-135. 
26. Mollah AH, Nahar N, Siddique A, Anwar KS, Hassan T, Azam G. Common transfusiontransmitted infectious agents among thalassaemic children in Bangladesh. HEALTH POPUL NUTR 2003; 21(1): 67-71.

27. Junaid M, Siddique AN, Khan MTM, Alam I, Waqas M, Hameed $S$ et al. Detection \& prevalence of hepatitis $B, C$ \& HIV viral infections among hemophilia patients in Peshawar, Pakistan. J Entomol Zool St 2017; 5(2): 180184.

28. Shamsdin SA, Sepehrimanesh M, Pezeshki B, Nejabat M. Seroprevalence of Hepatitis B \& C in patients with Hemophilia: A Single-Centre Descriptive Study. Shiraz E-Med J. 2015; 16(7): 1-3.

29. Brower C, Riley L, Womack M. Hepatitis \& Hemophilia. National Hemophilia Foundation 2012; 1-20.

30. Sharifi-Mood $B^{1}$, Eshghi $P$, Sanei-Moghaddam E, Hashemi M. Hepatitis B \& C virus infections in patients with hemophilia in Zahedan, southeast Iran. Saudi Med J. 2007; 28(10): 15161519.

31. Ghanaei FM, Fallah MS, Shafaghi A. Mashhoor MY, Ramezani N, Farzaneh F et al. Prevalence of hepatitis B \& C seromarkers \& abnormal liver function tests among hemophiliacs in Guilan (northern province of Iran). Med Sci Monit 2002; 8(12): CR797-800.

32. National Guidelines. Screening donated blood for transfusion transmissible infections in Bangladesh. 2013; 1-33.

33. American red cross, Blood testing. 2017.

34. Australian red cross. Australian red cross blood service: Donate blood 2016.

35. U.S. Food \& Drug administration. Complete list of donor screening assays for infectious agents \& HIV diagnostic assays. FDA, 2016.

36. UK NHS Blood \& transplant. Tests we carry out, 2015.

37. Singapore Health Science Authority. Blood donor testing, 2017.

38. Hans R \& Marwaha N. Nucleic acid testing benefits \& constraints. Asin J Transfus Sci 2014; 8(1): 2-3.
39. Centers for disease control \& prevention. Donor screening \& testing. Atlanta, CDC; 2013.

40. Rabbi FJ, Alam MM, Rezwan K, Sultana R. Hepatitis B virus infection \& anti-HBc (Total) positivity in CKD patients before dialysis. J Enam Med Col 2016; 6(3): 128-133.

41. Rahman MZ, Alam MR, Parveen S, Ahmed DS, Rahman MA, Chowdhury MS. Anti-HBc (Total) as a screening assay for safety of donated blood. Bang Med J. 2012; 41(3): 42-44.

42. Shil N, Biswas J, Khatun A, Rahman A, Sultana $\mathrm{N}$, Yasmin $\mathrm{F}$ et al. Incidence of anti-HBc antibody ( $\lg$ \& \& IgM) among HBsAg negative apparently healthy blooddonors. Bangab\&hu Sheikh Mujib Med. Univ. j. 2016; 9(4): 1-7.

43. Stramer SL, Wend U, C\&otti D, Foster GA, Hollinger B, Dodd RY et al. NucleicAcid Testing to Detect HBV Infection in Blood Donors. N Engl J Med 2011; 364: 236-247.

44. Bhattacharya P, Ch\&ra PK, Datta S, et al. Significant increase in HBV, HCV, HIV \& syphilis infections among blood donors in West Bengal, Eastern India 2004-2005: exploratory screening reveals high frequency of occult HBV infection. World J Gastroenterol 2007;13: 37303733.

45. Asim M, Ali R, Khan LA, Husain SA, Singla R, Kar P. Significance of anti-HB screening of blood donors \& its association with occult hepatitis $B$ virus infection: implications for blood transfusion. Indian J Med Res. 2010; 132: 312-317.

46. Behzad-Behbahani A, Mafi-Nejad A, Tabei SZ, Lankarani KB, Torab A, Moaddeb A. Anti-HBc \& HBV-DNA detection in blood donors negative for hepatitis $B$ virus surface antigen in reducing risk of transfusion associated HBV infection. Indian J Med Res. 2006; 123: 37-44.

47. Bhatti FA, Ullah Z, Salamat N, Ayub M, Ghani E. Anti-hepatitis B core antigen testing, viral markers, \& occult hepatitis $B$ virus infection in Pakistani blood donors: implications for transfusion practice. Transfusion (Paris). 2007; 47: 74-79.

48. Ramia S, Ramlawi F, Kanaan M, Klayme S, Naman R. Frequency \& significance of antibodies against hepatitis B core (anti-HBc) antigen as the only serological marker for hepatitis $B$ 
infection in Lebanese blood donors. Epidemiol Infect. 2005; 133: 695-699.

49. Pathology \& Lab Centre, Square Hospital Limited. Web address http://www.square hospital.com/?q=content/pathology-lab centre.

50. Blood Bank, Apollo Hospitals, Dhaka. Web address http://www.apollodhaka. com/bloodbank-2/\#about.

51. Ashraf $\mathrm{H}$, Alam $\mathrm{NH}$, Rothermundt $\mathrm{C}$, et al. Prevalence \& risk factors of hepatitis B \& C virus infections in an impoverished urban community in Dhaka, Bangladesh. BMC Infect Dis. 2010; 10: 208.

52. Wang JT, Lee CZ, Chen PJ, Wang TH, Chen DS. Transfusion-transmitted HBV infection in an endemic area: the necessity of more sensitive screening for HBV carriers. Transfusion (Paris). 2002; 42: 1592-597.

53. National Guidelines. Transfusion Transmissible Infections: Testing at Blood Transfusion Centers. External Quality Assessment Report Bangladesh: 2013. 